\title{
Modification of Structure and Magnetic Properties in Coordination Assemblies Based on [Cu(cyclam) $]^{2+}$ and $\left[\mathrm{W}(\mathrm{CN})_{8}\right]^{3-}$
}

\author{
Aleksandra Pacanowska, Mateusz Reczyński and Beata Nowicka * \\ Jagiellonian University in Krakow, Faculty of Chemistry, Gronostajowa 2, 30-387 Kraków, Poland; \\ o.pacanowska@gmail.com (A.P.); mateusz.reczynski@uj.edu.pl (M.R.) \\ * Correspondence: beata.nowicka@uj.edu.pl; Tel.: +48-12-686-2475
}

Received: 14 December 2018; Accepted: 10 January 2019; Published: 16 January 2019

check for updates

\begin{abstract}
The 1D $\left\{\left[\mathrm{Cu}^{\mathrm{II}}(\text { cyclam })\right]_{3}\left[\mathrm{~W}^{\mathrm{V}}(\mathrm{CN})_{8}\right]_{2} \cdot 5 \mathrm{H}_{2} \mathrm{O}\right\}_{\mathrm{n}} \quad\left(\mathbf{1} \cdot \mathbf{5} \mathbf{H}_{\mathbf{2}} \mathbf{O}\right) \quad($ cyclam $=1,4,8,11-$ tetraazacyclotetradecane) coordination polymer of ladder topology can be obtained in water-alcohol solution from $[\mathrm{Cu}(\mathrm{cyclam})]^{2+}$ and $\left[\mathrm{W}(\mathrm{CN})_{8}\right]^{3-}$ building blocks. Upon dehydration, $\mathbf{1} \cdot 5 \mathrm{H}_{2} \mathrm{O}$ undergoes a single-crystal-to-single-crystal structural transformation to the anhydrous $\left\{\left[\mathrm{Cu}^{\mathrm{II}}(\mathrm{cyclam})\right]_{3}\left[\mathrm{~W}^{\mathrm{V}}(\mathrm{CN})_{8}\right]_{2}\right\}_{n}$ (1) form, which retains the same topology, but is characterized by shorter $\mathrm{Cu}-\mathrm{W}$ distances and significantly more bent $\mathrm{CN}$-bridges. The deformation of the coordination skeleton is reflected in magnetic properties: the predominant intra-chain interactions change from ferromagnetic in $\mathbf{1} \cdot \mathbf{5} \mathrm{H}_{\mathbf{2}} \mathrm{O}$ to antiferromagnetic in $\mathbf{1}$. The reaction between the same building blocks in water solution under slow diffusion conditions leads to the formation of a $0 \mathrm{D}$ $\left\{\left[\mathrm{Cu}^{\mathrm{II}}(\mathrm{cyclam})\left(\mathrm{H}_{2} \mathrm{O}\right)\right]_{2}\left[\mathrm{Cu}^{\mathrm{II}}(\mathrm{cyclam})\right]\left[\mathrm{W}^{\mathrm{V}}(\mathrm{CN})_{8}\right]_{2}\right\} \cdot 3 \mathrm{H}_{2} \mathrm{O}$ pentanuclear assembly $\left(\mathbf{2} \cdot \mathbf{3} \mathbf{H}_{\mathbf{2}} \mathbf{O}\right)$.
\end{abstract}

Keywords: molecular magnetism; octacyanotungstate(V); copper(II); cyclam; cyano bridge; magnetic properties

\section{Introduction}

One of the interesting features that can be achieved in molecular magnetics is the possibility to modify magnetic properties by sorption of small guest molecules. At the turn of the century magnetic sponges was defined as compounds that change structure and magnetic properties upon reversible removal of coordinated or non-coordinated water molecules [1-3]. Later, the term solvatomagnetism was introduced to describe changes in magnetic behavior upon sorption or desorption of different guest molecules.

We have previously shown that the solvatomagnetic effect can be repeatedly observed in $\mathrm{CN}$-bridged networks containing the $[\mathrm{Ni}(\mathrm{cyclam})]^{2+/ 3+}$ cationic building block. By combining it with different polycyanometallates, we obtained two main families of coordination polymers of 1D and 2D connectivity. The $2 \mathrm{D}\left\{\left[\mathrm{Ni}^{\mathrm{II}}(\text { cyclam })\right]_{3}\left[\mathrm{M}(\mathrm{CN})_{\mathrm{n}}\right]_{2}\right\}_{\infty}\left(\mathrm{M}=\mathrm{Cr}^{\mathrm{III}}, \mathrm{Fe}^{\mathrm{III}}, \mathrm{n}=6 ; \mathrm{M}=\mathrm{W}^{\mathrm{V}}, \mathrm{n}=8\right)$ networks [4-7] show honeycomb-like topology with microporous channels running across the coordination layers. For these networks, we observed formation of different hydrates as well as the possibility to introduce small organic molecules. For each of the three compounds, four pseudopolymorphic forms differing in structure and magnetic properties have been characterized. The second family of solvatomagnetic polymers are non-porous $1 \mathrm{D}$ bimetallic alternating chains. The $\left\{\left[\mathrm{Ni}^{\mathrm{III}}(\mathrm{cyclam})\right]\left[\mathrm{M}^{\mathrm{III}}(\mathrm{CN})_{6}\right]_{2} \cdot 6 \mathrm{H}_{2} \mathrm{O}\right\}_{\infty}$ $\left(\mathrm{M}^{\mathrm{III}}=\mathrm{Cr}, \mathrm{Fe}\right)[8]$ chains can be reversibly dehydrated, which affects their magnetic properties. The $\left\{\left(\mathrm{H}_{3} \mathrm{O}\right)\left[\mathrm{Ni}^{\mathrm{III}}(\text { cyclam })\right]\left[\mathrm{M}^{\mathrm{II}}(\mathrm{CN})_{6}\right]_{2} \cdot 5 \mathrm{H}_{2} \mathrm{O}\right\}_{\infty}\left(\mathrm{M}^{\mathrm{II}}=\mathrm{Fe}\right.$, [9] $\mathrm{Ru}$, Os [10]) chains, where the charge of the coordination skeleton is compensated by the presence of the $\mathrm{H}_{3} \mathrm{O}^{+}$ions, are rare examples of sorption-driven charge-transfer. The removal of water causes partial electron transfer from $\mathrm{M}^{\mathrm{II}}$ centers to $\mathrm{Ni}^{\mathrm{III}}$ ions. The process is reversible for $\mathrm{Fe}^{\mathrm{II}}$ and irreversible for $\mathrm{Ru}^{\mathrm{II}}$ and $\mathrm{Os}^{\mathrm{II}}$-based compounds. 
Cyclam complexes with different metal centers, including $\mathrm{Ni}^{\mathrm{II}}$ [11,12], $\mathrm{Cu}^{\mathrm{II}}$ [13-17] and $\mathrm{Mn}^{\mathrm{III}}$ [18-20], were often used to build CN-bridged coordination polymers. However, apart from our studies, there are no reports on the desolvation effects in this group of compounds. Thus, we decided to examine the potential of cyclam complexes with other metal ions for the construction of solvatomagnetic materials. The manganese(III)-based alternating bimetallic chains $\left\{\left[\mathrm{Ni}^{\mathrm{III}}(\text { cyclam })\right]\left[\mathrm{M}^{\mathrm{III}}(\mathrm{CN})_{6}\right]_{2} \cdot 6 \mathrm{H}_{2} \mathrm{O}\right\}_{\infty}\left(\mathrm{M}^{\mathrm{III}}=\mathrm{Cr}, \mathrm{Fe}\right)$ exhibit loss of crystallization water accompanied by structural and magnetic changes [21]; however, in contrast to their $\mathrm{Ni}{ }^{\mathrm{III}}$-based congeners [8], the dehydration process was irreversible. The $\mathrm{Cu}^{\mathrm{II}}$ cationic building blocks often differ from those of other $3 \mathrm{~d}$ metals, due to the strong Jahn-Teller effect. The $\left\{\left[\mathrm{Cu}^{\mathrm{II}}(\mathrm{cyclam})\right]_{3}\left[\mathrm{~W}^{\mathrm{V}}(\mathrm{CN})_{8}\right]_{2} \cdot 5 \mathrm{H}_{2} \mathrm{O}\right\}_{\mathrm{n}}$ compound [22] shows 1D ladder-like topology, unlike the series of $\mathrm{Ni}^{\mathrm{II}}$-based $2 \mathrm{D}$ honeycomb-like networks of the same stoichiometry described above. It was characterized in terms of structure and magnetic properties, but dehydration effect was not mentioned in the report [22]. Here, we present the post-synthetic modification of structure and magnetic properties of this ladder chain network and the synthesis of a new $0 \mathrm{D}$ assembly based on the same building blocks.

\section{Materials and Methods}

The $\mathrm{Na}_{3}\left[\mathrm{~W}(\mathrm{CN})_{8}\right] \cdot 4 \mathrm{H}_{2} \mathrm{O}$ precursor complex was prepared according to the published procedure [23]. Other reagents and solvents were commercially available and used as supplied. Measurements of powder X-ray diffraction were carried out on a PANanalitical X'Pert Pro powder diffractometer with the $\mathrm{Cu} K \alpha$ radiation source. Elemental analysis for carbon, nitrogen and hydrogen were carried out on a Vario Micro Cube elemental analyser. IR spectra of single crystals were recorded using a Nicolet iN10 MX FTIR microscope operating in the transmission mode. The dehydration process was characterized by a dynamic vapor sorption method using an SMS DVS Resolution apparatus in the $40-0 \% \mathrm{RH}$ range at $298 \mathrm{~K}$. Magnetic measurements were performed on a Quantum Design MPMS3 magnetometer. Variable-temperature magnetic susceptibility was measured at an applied field of $1000 \mathrm{Oe}$ in the temperature range of $300 \mathrm{~K}$ to $1.8 \mathrm{~K}$ and magnetization at $1.8 \mathrm{~K}$ up to $70 \mathrm{kOe}$. The samples were sealed in polyethylene bags to avoid dehydration at low pressure.

\subsection{Synthesis of the $[\mathrm{Cu}(\mathrm{cyclam})]\left(\mathrm{NO}_{3}\right)_{2} \cdot 6 \mathrm{H}_{2} \mathrm{O}$ Precursor Complex}

The compound was prepared according to the modified published procedure [24]. $\mathrm{Cu}\left(\mathrm{NO}_{3}\right)_{2} \cdot 3 \mathrm{H}_{2} \mathrm{O}(1 \mathrm{mmol}, 245.4 \mathrm{mg})$ was dissolved in $4 \mathrm{ml}$ of absolute ethanol at $60{ }^{\circ} \mathrm{C}$. To the above solution, solid cyclam ( $1 \mathrm{mmol}, 200.0 \mathrm{mg}$ ) was added and immediate precipitation of violet product was observed. The suspension was left in the freezer for $1 \mathrm{~h}$ and then filtered. Yield: $396.0 \mathrm{mg}(79 \%)$.

\subsection{Synthesis of $\left\{[\mathrm{Cu}(\text { cyclam })]_{3}\left[\mathrm{~W}(\mathrm{CN})_{8}\right]_{2} \cdot 5 \mathrm{H}_{2} \mathrm{O}\right\}_{n}\left(\mathbf{1} \cdot \mathbf{5} \mathbf{H}_{\mathbf{2}} \mathbf{O}\right)$}

The compound was prepared according to the modified published procedure [22]. A solution of $[\mathrm{Cu}($ cyclam $)]\left(\mathrm{NO}_{3}\right)_{2} \cdot 6 \mathrm{H}_{2} \mathrm{O}(0.13 \mathrm{mmol}, 66.4 \mathrm{mg})$ in a water-ethanol mixture $(1: 2,20 \mathrm{~mL})$ was layered over a solution of $\mathrm{Na}_{3}\left[\mathrm{~W}(\mathrm{CN})_{8}\right] \cdot 4 \mathrm{H}_{2} \mathrm{O}(0.07 \mathrm{mmol}, 35.6 \mathrm{mg})$ in a water-ethanol mixture $(2: 1,20 \mathrm{~mL})$ in test tubes. Brownish-red needle-shaped crystals were formed after three days. (Found: $\mathrm{C}, 33.53 ; \mathrm{H}$, 4.976; N, 23.44; calc. $\mathrm{C}_{46} \mathrm{H}_{82} \mathrm{Cu}_{3} \mathrm{~N}_{28} \mathrm{O}_{5} \mathrm{~W}_{2}$ : C, 33.17; H, 4.96; N, 23.55) IR $v \mathrm{CN}: 2167 \mathrm{~cm}^{-1}, 2151 \mathrm{~cm}^{-1}$, $2145 \mathrm{~cm}^{-1}, 2139 \mathrm{~cm}^{-1}$.

\subsection{Synthesis of $\left\{[\mathrm{Cu}(\mathrm{cyclam})]_{3}\left[W(\mathrm{CN})_{8}\right]_{2}\right\}_{n}(\mathbf{1})$}

The anhydrous compound was obtained by drying $1 \cdot 5 \mathbf{H}_{2} \mathbf{O}$ at $50{ }^{\circ} \mathrm{C}$ for $1 \mathrm{~h}$. IR $v \mathrm{CN}: 2166 \mathrm{~cm}^{-1}$, $2161 \mathrm{~cm}^{-1}, 2151 \mathrm{~cm}^{-1}, 2144 \mathrm{~cm}^{-1}, 2139 \mathrm{~cm}^{-1}, 2134 \mathrm{~cm}^{-1}$

\subsection{Synthesis of $\left\{\left[C u^{I I}(\text { cyclam })\left(\mathrm{H}_{2} \mathrm{O}\right)\right]_{2}\left[C u^{I I}(\right.\right.$ cyclam $\left.\left.)\right]\left[W^{V}(C N)_{8}\right]_{2}\right\} \cdot 3 \mathrm{H}_{2} \mathrm{O}\left(\mathbf{2} \cdot \mathbf{3} \mathbf{H}_{\mathbf{2}} \mathbf{O}\right)$}

The solutions of $[\mathrm{Cu}(\mathrm{cyclam})]\left(\mathrm{NO}_{3}\right)_{2} \cdot 6 \mathrm{H}_{2} \mathrm{O}\left(0.05 \mathrm{mmol}, 26.8 \mathrm{mg}\right.$ in $8 \mathrm{~mL}$ of $\left.\mathrm{H}_{2} \mathrm{O}\right)$ and $\mathrm{Na}_{3}\left[\mathrm{~W}(\mathrm{CN})_{8}\right] \cdot 4 \mathrm{H}_{2} \mathrm{O}\left(0.03 \mathrm{mmol}, 14.5 \mathrm{mg}\right.$ in $8 \mathrm{~mL}$ of $\left.\mathrm{H}_{2} \mathrm{O}\right)$ were placed in separate sections of an 
H-tube and water was added to fill the horizontal connecting tube. Brownish-red plate-shaped crystals were formed after $2-3$ weeks. (Found: $\mathrm{C}, 33.42 ; \mathrm{H}, 4.76 ; \mathrm{N}, 23.53 ;$ cal. $\mathrm{C}_{46} \mathrm{H}_{82} \mathrm{Cu}_{3} \mathrm{~N}_{28} \mathrm{O}_{5} \mathrm{~W}_{2}$ : C, 33.17; $\mathrm{H}$, 4.96; N, 23.55). IR vCN: $2166 \mathrm{~cm}^{-1}, 2151 \mathrm{~cm}^{-1}, 2144 \mathrm{~cm}^{-1}, 2139 \mathrm{~cm}^{-1}$.

\subsection{Structure Determination}

Single crystal X-ray diffraction measurements for $\mathbf{1}$ and $\mathbf{2} \cdot \mathbf{3} \mathbf{H}_{\mathbf{2}} \mathbf{O}$ were performed on a Bruker D8 QUEST diffractometer. The structures were solved by direct methods using SHELXT [25]. Refinement and further calculations were carried out using SHELXL [25]. The non-H atoms were refined anisotropically, apart from some $\mathrm{O}$ atoms of disordered crystallization water, which were refined isotropically. $\mathrm{H}$-atoms were placed in idealized positions and refined using riding model. $\mathrm{H}$-atoms were not considered for disordered water molecules in $\mathbf{2} \cdot \mathbf{3} \mathbf{H}_{\mathbf{2}} \mathbf{O}$; however, they were included in the calculation of the molecular weight. The unit cell of $\mathbf{1}$ was transformed in

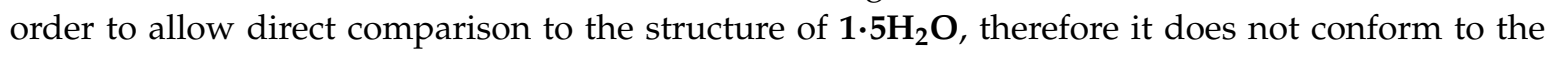
requirements of a reduced cell. Due to high absorption and relatively poor quality of the crystals of 1 after solid state transformation, some residual electron density peaks appear around W. The crystallographic data for $\mathbf{1}$ and $\mathbf{2 \cdot 3} \mathbf{H} \mathbf{2 O}$ are presented in Table 1, with structure parameters for $\mathbf{1 \cdot 5 \mathbf { H } _ { 2 }} \mathrm{O}$ [22] added for comparison. Graphics were created with Mercury 3.9.10. The analysis of coordination polyhedra was performed using SHAPE 2.1 [26]. CCDC 1885028 and 1885029 contain the supplementary crystallographic data for this paper. These data can be obtained free of charge via http: / / www.ccdc.cam.ac.uk/conts / retrieving.html

Table 1. Structure and refinement data for $\mathbf{1}$ and $\mathbf{2} \cdot \mathbf{3} \mathrm{H}_{2} \mathrm{O}$; data for $\mathbf{1} \cdot \mathbf{5} \mathrm{H}_{\mathbf{2}} \mathrm{O}$ included for comparison.

\begin{tabular}{|c|c|c|c|}
\hline & $1 \cdot 5 \mathrm{H}_{2} \mathrm{O}^{1}$ & 1 & $2 \cdot 3 \mathrm{H}_{2} \mathrm{O}$ \\
\hline Empirical formula & $\mathrm{C}_{46} \mathrm{H}_{82} \mathrm{Cu}_{3} \mathrm{~N}_{28} \mathrm{O}_{5} \mathrm{~W}_{2}$ & $\mathrm{C}_{46} \mathrm{H}_{72} \mathrm{Cu}_{3} \mathrm{~N}_{28} \mathrm{~W}_{2}$ & $\mathrm{C}_{46} \mathrm{H}_{82} \mathrm{Cu}_{3} \mathrm{~N}_{28} \mathrm{O}_{5} \mathrm{~W}_{2}$ \\
\hline Formula weight & 1665.72 & 1575.57 & 1665.72 \\
\hline Crystal system & triclinic & triclinic & monoclinic \\
\hline Space group & $P-1$ & $P-1$ & $P 2_{1} / n$ \\
\hline a $[\AA ̊]$ & $8.9255(11)$ & $9.0228(5)$ & $14.0566(7)$ \\
\hline $\mathrm{b}[\AA]$ & $10.0938(13)$ & $10.8399(8)$ & $12.8685(7)$ \\
\hline c $[\AA]$ & $19.549(3)$ & $17.8734(13)$ & $36.7198(19)$ \\
\hline$\alpha\left[^{\circ}\right]$ & $78.342(5)$ & $75.409(6)$ & 90.0 \\
\hline$\beta\left[^{\circ}\right]$ & $83.074(5)$ & $87.810(4)$ & $100.821(2)$ \\
\hline$\gamma\left[{ }^{\circ}\right]$ & $69.472(5)$ & $60.092(7)$ & 90.0 \\
\hline $\mathrm{V}\left[\AA^{3}\right]$ & $1613.0(4)$ & $1458.5(8)$ & $6524.0(3)$ \\
\hline $\mathrm{Z}$ & 1 & 1 & 4 \\
\hline $\mathrm{dc}\left[\mathrm{g} \cdot \mathrm{cm}^{-3}\right]$ & 1.715 & 1.794 & 1.696 \\
\hline$\mu\left[\mathrm{mm}^{-1}\right]$ & 4.590 & 5.064 & 4.539 \\
\hline $\mathrm{F}(000)$ & 829 & 779 & 3276 \\
\hline$\theta$ range $\left[{ }^{\circ}\right]$ & $1.07-28.28$ & $2.79-25.4$ & $2.37-29.15$ \\
\hline Reflns collected & 21,064 & 5261 & 17,526 \\
\hline No. of params & 380 & 356 & 746 \\
\hline $\mathrm{R}_{\text {int }}$ & 0.0693 & 0.0532 & 0.0362 \\
\hline $\operatorname{GooF}\left(\mathrm{F}^{2}\right)$ & - & 1.018 & 1.059 \\
\hline $\mathrm{R}_{1}[\mathrm{I}>2 \sigma(\mathrm{I})]$ & 0.0693 & 0.0708 & 0.0446 \\
\hline$\omega R_{2}$ (all data) & 0.1662 & 0.1510 & 0.0973 \\
\hline
\end{tabular}

\section{Results and Discussion}

\subsection{Synthesis and Post-Synthetic Modification}

The reaction between $[\mathrm{Cu}(\text { cyclam })]^{2+}$ and $\left[\mathrm{W}(\mathrm{CN})_{8}\right]^{3-}$ building blocks in water-alcohol solution leads to the formation of $\left\{\left[\mathrm{Cu}^{\mathrm{II}}(\text { cyclam })\right]_{3}\left[\mathrm{~W}^{\mathrm{V}}(\mathrm{CN})_{8}\right]_{2} \cdot 5 \mathrm{H}_{2} \mathrm{O}\right\}_{\mathrm{n}}\left(\mathbf{1} \cdot \mathbf{5} \mathbf{H}_{\mathbf{2}} \mathrm{O}\right)$ of the ladder-chain structure reported earlier [22]. The crystals of $\mathbf{1 \cdot 5} \mathbf{H}_{\mathbf{2}} \mathbf{O}$ are stable under ambient conditions, but at slightly 
elevated temperatures $\left(30-50{ }^{\circ} \mathrm{C}\right)$, they lose crystallization water to result in an anhydrous $\left\{\left[\mathrm{Cu}^{\mathrm{II}}(\mathrm{cyclam})\right]_{3}\left[\mathrm{~W}^{\mathrm{V}}(\mathrm{CN})_{8}\right]_{2}\right\}_{n}$ (1) form. The process occurs with retention of crystallinity and thus the structure of $\mathbf{1}$ could be established from a single crystal XRD measurement. The single-crystal-to-single-crystal structural transformations upon desolvation are relatively rare $[5,27,28]$. In the family of the coordination polymers based on $[\mathrm{Ni}(\mathrm{cyclam})]^{2+/ 3+}$ ions and polycyanometallates, we observed this phenomenon only for the $2 \mathrm{D}\left\{\left[\mathrm{Ni}^{\mathrm{II}}(\mathrm{cyclam})\right]_{3}\left[\mathrm{~W}^{\mathrm{V}}(\mathrm{CN})_{8}\right]_{2}\right\}_{\infty}$ network [5]. The crystals of 1 exposed at $25{ }^{\circ} \mathrm{C}$ to humid air $(40-60 \% \mathrm{RH})$ regain their original composition. However, upon rehydration, the crystals collapse and the PXRD results (Figure S1) show that the rehydration process leads to a mixture of phases, one of which is the original $\mathbf{1} \cdot 5 \mathrm{H}_{\mathbf{2}} \mathrm{O}$ form. We followed the dehydration process using the gravimetric dynamic vapor sorption method. The sample was subjected to decreasing relative humidity from $40 \%$ to $0 \%$ at a constant temperature of $298 \mathrm{~K}$. The sharp decrease in mass starts at about 15\% RH (Figure S2), and takes place in two unresolved steps, which correspond to the subsequent loss of 3 and 2 water molecules.

When the reaction between the same building blocks is carried out in a water solution under slow diffusion conditions, a $0 \mathrm{D}$ pentanuclear assembly of the formula $\left\{\left[\mathrm{Cu}^{\mathrm{II}}(\text { cyclam })\left(\mathrm{H}_{2} \mathrm{O}\right)\right]_{2}\left[\mathrm{Cu}^{\mathrm{II}}(\right.\right.$ cyclam $\left.\left.)\right]\left[\mathrm{W}^{\mathrm{V}}(\mathrm{CN})_{8}\right]_{2} \cdot 3 \mathrm{H}_{2} \mathrm{O}\right\}\left(\mathbf{2} \cdot \mathbf{3} \mathbf{H}_{\mathbf{2}} \mathrm{O}\right)$ is obtained. Interestingly, quick precipitation from the water solution does not lead to the same result. The analysis of the PXRD patterns (Figure S3) suggests that $\mathbf{1} \cdot \mathbf{5} \mathbf{H}_{\mathbf{2}} \mathrm{O}$ is formed instead. Similar disparity between the course of slow diffusion and quick precipitation reactions was observed for the $3 \mathrm{D}\left\{\left[\mathrm{Ni}^{\mathrm{II}}(\text { cyclam })\right]_{2}\left[\mathrm{~W}^{\mathrm{IV}}(\mathrm{CN})_{8}\right]\right\}_{\infty}$ network [29]. Due to a very low yield and long time taken to grow crystals, the dehydration of $\mathbf{2} \cdot \mathbf{3} \mathbf{H}_{\mathbf{2}} \mathrm{O}$ was not studied, but it seems likely that both lattice and coordinated water could be removed, possibly with the formation of additional CN-bridges between neighboring molecules.

\subsection{Description of Structures}

Upon dehydration of $\mathbf{1} \cdot \mathbf{5} \mathbf{H}_{\mathbf{2}} \mathrm{O}$, the triclinic system and space group P-1 are retained, but cell parameters change significantly (Table 1$)$. In particular, period $c$ shortens by $1.7 \AA(8.7 \%)$ and the $\gamma$ angle decreases by $9.38^{\circ}(13.5 \%)$. The cell volume decreases by $155 \AA^{3}(9.6 \%)$ per formula unit, which corresponds quite well to the volume expected for five H-bound water molecules. The connectivity of the coordination network is retained, with $\mathrm{Cu}$ and $\mathrm{W} \mathrm{CN}$-bridged centers forming a 1D ladder-like chain. Apart from the removed water molecules, the asymmetric unit of 1 (Figure 1) contains the same set of atoms as $\mathbf{1} \cdot 5 \mathrm{H}_{\mathbf{2}} \mathrm{O}$, including $\mathrm{Cu} 1$ and $\mathrm{W} 1$ ions located in general positions and $\mathrm{Cu} 2$ ions in the inversion center. Each tungsten center (W1) is coordinated by eight cyanide ligands, three of which form bridges to copper centers (two $\mathrm{Cu} 1$ and one $\mathrm{Cu} 2$ ). The copper ions are connected with two tungsten centers through cyanide bridges coordinated in axial positions, with equatorial positions blocked by the cyclam ligand. The dehydration process strongly affects the geometry of CN-bridges and coordination polyhedra. The Continuous Shape Measure analysis [26] shows that the geometry of the $\left[\mathrm{W}(\mathrm{CN})_{8}\right]^{3-}$ ion in the hydrated form $\mathbf{1} \cdot 5 \mathrm{H}_{2} \mathrm{O}$ is close to square antiprism, while for the anhydrous form (1), it changes to a triangular dodecahedron (Table S1). Both $\mathrm{Cu}$ ions in $\mathbf{1} \cdot \mathbf{5} \mathbf{H}_{\mathbf{2}} \mathrm{O}$ show a highly distorted octahedral geometry (Table S2), due to the significant Jahn-Teller effect causing elongation of the axial bonds. The non-centrosymmetric $\mathrm{Cu} 1$ center is more distorted, due to the asymmetry of the axial bonds, one of which (Cu1-N1 of $2.698 \AA$ ) can be classified as a semi-coordination bond. Upon dehydration, the Cu2-N5 distances shorten by $0.053 \AA$, while the Cu2-N distances become more symmetrical (Table 2). As an effect, the octahedral geometry of both copper centers in the anhydrous form 1 is less distorted (Table S2). The angles of cyanide bridges (Cu1-N1-C1, Cu1-N4-C4, Cu2-N5-C5) decrease by $13.74-24.78^{\circ}$ (Table 2). Therefore, dehydration leads to significant shortening of the distances between the CN-linked metal centers by $0.219-0.392 \AA$. 


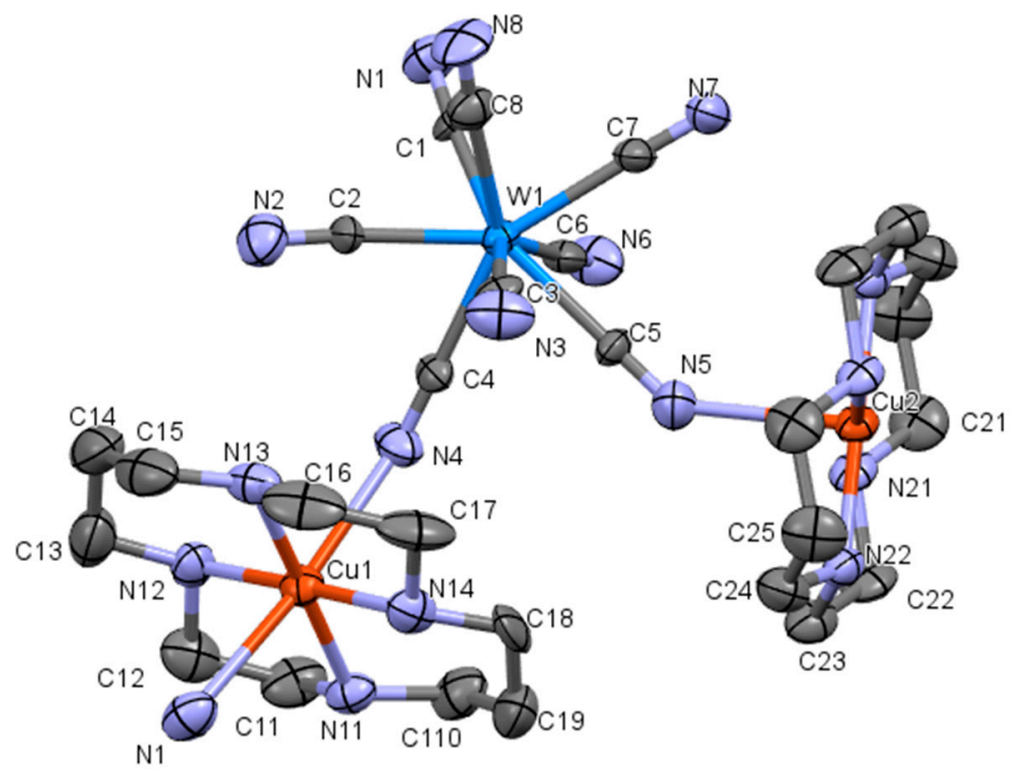

Figure 1. The asymmetric unit of $\mathbf{1}$ with atom numbering; ellipsoids at $50 \%$ probability.

Table 2. Selected bond lengths $(\AA)$ and angles $\left(^{\circ}\right)$ in $\mathbf{1} \cdot \mathbf{5} \mathbf{H}_{2} \mathrm{O}$ and $\mathbf{1}$.

\begin{tabular}{|c|c|c|c|c|c|}
\hline Bond & $1 \cdot 5 \mathrm{H}_{2} \mathrm{O}^{1}$ & 1 & Angle & $1 \cdot 5 \mathrm{H}_{2} \mathrm{O}^{1}$ & 1 \\
\hline W1-C1 & 2.181 & 2.149 & Cu1-N1-C1 & 143.0 & 129.3 \\
\hline W1-C2 & 2.157 & 2.129 & Cu1-N4-C4 & 157.1 & 135.3 \\
\hline W1-C3 & 2.154 & 2.159 & Cu2-N5-C5 & 157.1 & 142.1 \\
\hline W1-C4 & 2.169 & 2.155 & N11-Cu1-N12 & 93.22 & 86.1 \\
\hline W1-C5 & 2.165 & 2.152 & N12-Cu1-N13 & 86.44 & 95.5 \\
\hline W1-C6 & 2.152 & 2.159 & N13-Cu1-N14 & 94.23 & 86.6 \\
\hline W1-C7 & 2.158 & 2.149 & N14-Cu1-N11 & 85.93 & 91.9 \\
\hline W1-C8 & 2.169 & 2.214 & N21-Cu2-N22 & 86.34 & 86.2 \\
\hline Cu1-N1 & 2.698 & 2.606 & W1-C1-N1 & 176.75 & 176.3 \\
\hline Cu1-N4 & 2.510 & 2.585 & W1-C4-N4 & 177.74 & 179.4 \\
\hline Cu2-N5 & 2.556 & 2.503 & W1-C5-N5 & 174.43 & 176.5 \\
\hline Cu1-N11 & 2.004 & 2.037 & & & \\
\hline Cu1-N12 & 2.023 & 2.027 & & & \\
\hline Cu1-N13 & 2.024 & 2.018 & & & \\
\hline Cu1-N14 & 2.014 & 1.998 & & & \\
\hline Cu2-N21 & 2.015 & 2.011 & & & \\
\hline Cu2-N22 & 2.032 & 2.028 & & & \\
\hline
\end{tabular}

Projections of structure along the crystallographic axes for $\mathbf{1} \cdot \mathbf{5} \mathbf{H}_{\mathbf{2}} \mathrm{O}$ and $\mathbf{1}$ (Figure 2) show the ladder-like topology retained upon dehydration. In both structures, the ladders lie in the (11-1) plane and run along the [1-10] direction. However, the changes in the coordination geometry of the $\left[\mathrm{W}(\mathrm{CN})_{8}\right]^{3-}$ ion and different alignment of the cyclam ligand in both forms are noticeable. Likewise, the bending of the $\mathrm{CN}$-bridges can be seen, particularly in the view along the a period. Upon dehydration, the distance between the neighboring chains in the [001] direction shortens, which is visible in the projections along the $b$ and $c$ axes. The distance between the $\mathrm{Cu} 1$ and $\mathrm{W} 1$ centers from the neighboring chains shortens by $0.725 \AA$. In the hydrated form $\mathbf{1} \cdot 5 \mathbf{H}_{\mathbf{2}} \mathbf{O}$, the coordination ladders are bound into a 3D supramolecular network by H-bonds between cyanide ligands, $\mathrm{NH}$ groups of the cyclam molecules, and crystallization water [22]. Upon loss of crystallization water, the hydrogen bonds are rearranged (Figure S4). The ladders are bound into stacks along the [110] direction, resulting in the 2D supramolecular network. Conversely, there is no connection in the [001] direction, despite shorter distance between the ladders. Moreover, due to the bending of $\mathrm{CN}$-bridges, intramolecular $\mathrm{H}$-bonds appear. They link the terminal $\mathrm{CN}$ ligands with the $\mathrm{NH}$ groups of cyclam from the $\mathrm{W} 1$ and 
$\mathrm{Cu} 1$ centers, and thus stabilize strong bending of the Cu1-N1-C1 bridge (Table 2). This may be the reason why the rehydration process leads to the collapse of crystals and is not fully reversible.

$a$
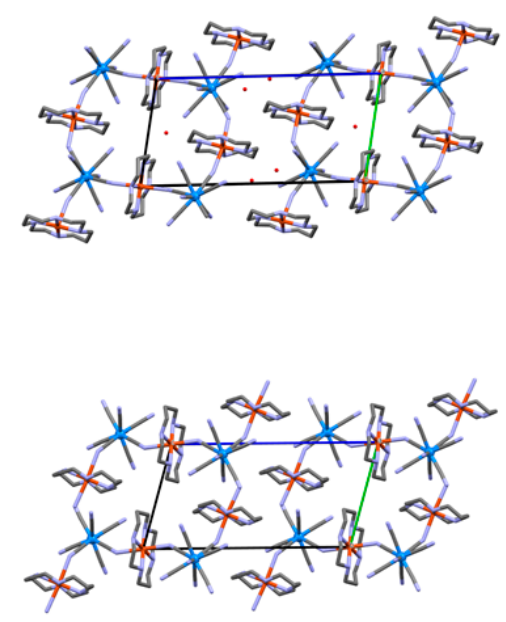

$b$

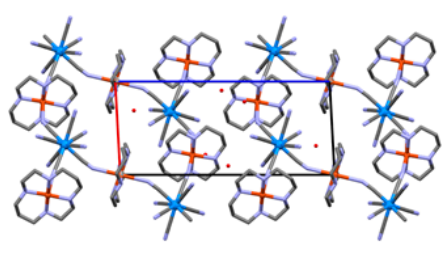

$1 \cdot 5 \mathrm{H}_{2} \mathrm{O}$

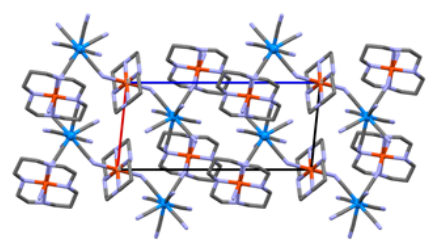

C
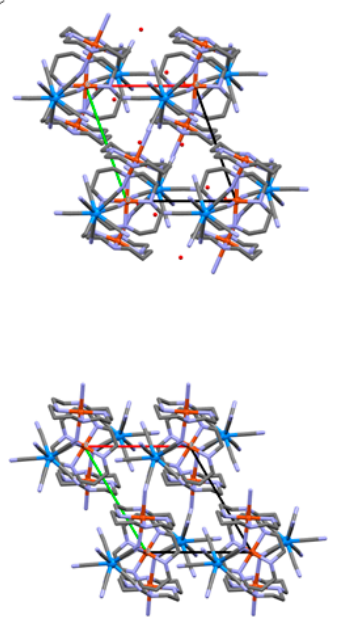

1

Figure 2. Projection of structures of $\mathbf{1} \cdot 5 \mathrm{H}_{2} \mathrm{O}$ and $\mathbf{1}$ along $(\mathrm{a}-\mathrm{c})$ crystallographic directions.

The $0 \mathrm{D}\left\{\left[\mathrm{Cu}^{\mathrm{II}}(\mathrm{cyclam})\left(\mathrm{H}_{2} \mathrm{O}\right)\right]_{2}\left[\mathrm{Cu}^{\mathrm{II}}(\right.\right.$ cyclam $\left.\left.)\right]\left[\mathrm{W}^{\mathrm{V}}(\mathrm{CN})_{8}\right]_{2}\right\} \cdot 3 \mathrm{H}_{2} \mathrm{O}$ assembly $\left(\mathbf{2} \cdot \mathbf{3} \mathbf{H}_{\mathbf{2}} \mathbf{O}\right)$ is obtained from the same building blocks as the $\mathbf{1} \cdot \mathbf{5} \mathbf{H}_{\mathbf{2}} \mathrm{O}$ ladder chain, but under different synthetic conditions. The compound crystallizes in a monoclinic system, space group P $2_{1} / \mathrm{n}$ (Table 1 ). Its structure is composed of Z-shaped pentanuclear molecules containing two W and three $\mathrm{Cu}$ centers connected by $\mathrm{CN}$-bridges with water molecules coordinated to the terminal $\mathrm{Cu}$ ions (Figure 3). There are two symmetrically independent molecules. Each of them is centrosymmetric with the central $\mathrm{Cu}$ ions located at the inversion centers. Therefore, the asymmetric unit consist of two tungsten and two copper centers (W1, W2, Cu1, Cu3) in general positions and two copper centers (Cu2 and Cu4) in special positions. Each $\mathrm{W}$ atom is coordinated by eight cyanide ligands, two of which form bridges to two $\mathrm{Cu}$ centers (W1 with $\mathrm{Cu} 1$ and $\mathrm{Cu} 2$; W2 with $\mathrm{Cu} 3$ and $\mathrm{Cu} 4$ ). The coordination geometry of both $\mathrm{W}$ centers is close to ideal square antiprism (Table S1). All $\mathrm{Cu}$ ions have cyclam ligand coordinated in equatorial positions. The centrosymmetric $\mathrm{Cu} 2$ and $\mathrm{Cu} 4$ atoms are linked by two cyanide bridges, whereas the $\mathrm{Cu} 1$ and $\mathrm{Cu} 3$ centers located at the ends of the Z-shaped molecule are coordinated by one cyanide bridge and one water molecule in axial positions. The octahedral coordination geometry is distorted due to the Jahn-Teller effect (Table S2). There is a large disproportion of the extent of this distortion between the centrosymmetric $\mathrm{Cu}$ centers: $\mathrm{Cu} 2$ with the very long and bent NC-bridges (Table 3) shows very large distortion, while $\mathrm{Cu} 4$ shows the lowest distortion among the $\mathrm{Cu}$ centers in $\mathbf{1}$ and $\mathbf{2}$.

The average length of the $\mathrm{Cu}-\mathrm{N}$ bond in the CN-bridge is $2.543 \AA$, which is shorter than for $\mathbf{1} \cdot 5 \mathbf{H}_{2} \mathrm{O}(2.588 \AA)$ or $\mathbf{1}(2.565 \AA)$. The average value of the $\mathrm{Cu}-\mathrm{N}-\mathrm{C}$ angles of the $\mathrm{CN}$-bridges $\left(147.87^{\circ}\right)$

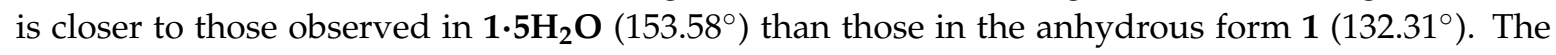
distances between the $\mathrm{CN}$-bridged metal centers are shorter for the central $\mathrm{Cu}$ (W1-Cu2, W2-Cu4) than for the terminal ones (W1-C1, W2-Cu3) by about $0.25 \AA$, due to the stronger bending of the central $\mathrm{CN}$ bridges. 


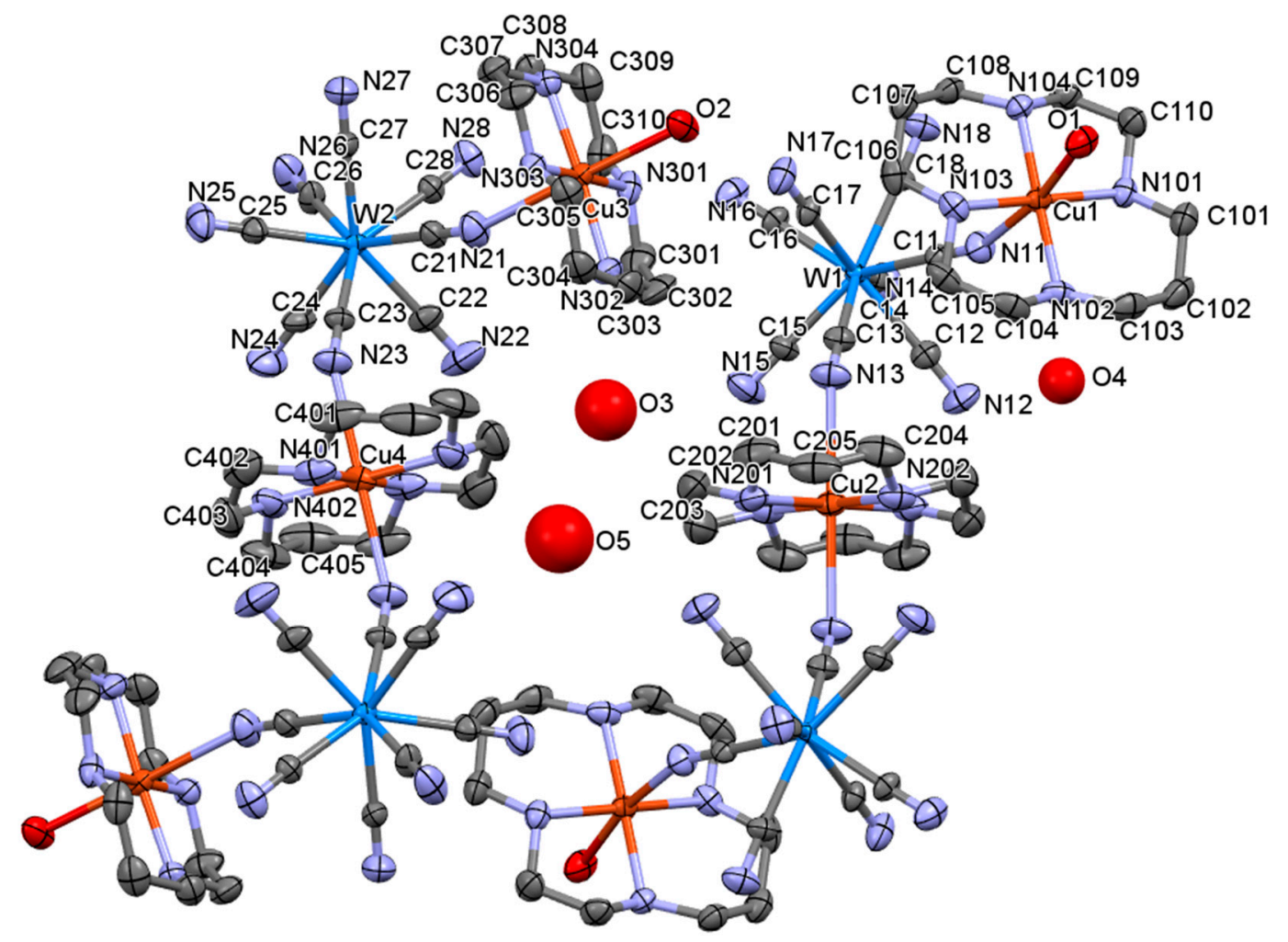

Figure 3. Structure of $\mathbf{2} \cdot \mathbf{3 H} \mathbf{H O}$ with atom numbering; ellipsoids at $50 \%$ probability.

Table 3. Selected bond lengths $(\AA)$ and angles $\left({ }^{\circ}\right)$ in $\mathbf{2} \cdot \mathbf{3} \mathbf{H}_{2} \mathbf{O}$.

\begin{tabular}{llll}
\hline Cu1-N11 & 2.523 & Cu1-N11-C11 & 157.9 \\
Cu1-O1 & 2.518 & Cu2-N13-C13 & 137.2 \\
Cu2-N13 & 2.596 & Cu3-N21-C21 & 153.9 \\
Cu3-N21 & 2.594 & Cu4-N23-C23 & 142.8 \\
Cu3-O2 & 2.422 & N101-Cu1-N102 & 93.3 \\
Cu4-N23 & 2.457 & N102-Cu1-N103 & 86.0 \\
Cu1-N101 & 2.013 & N103-Cu1-N104 & 95.0 \\
Cu1-N102 & 2.037 & N104-Cu1-N101 & 85.7 \\
Cu1-N103 & 2.011 & N201-Cu2-N202 & 86.0 \\
Cu1-N104 & 2.023 & N301-Cu3-N302 & 85.8 \\
Cu2-N201 & 2.008 & N302-Cu3-N303 & 92.8 \\
Cu2-N202 & 2.019 & N303-Cu3-N304 & 86.4 \\
Cu3-N301 & 2.021 & N304-Cu3-N301 & 95.0 \\
Cu3-N302 & 2.029 & N401-Cu4-N402 & 85.6 \\
Cu3-N303 & 2.008 & W1-C11-N11 & 178.5 \\
Cu3-N304 & 2.013 & W1-C13-N13 & 177.2 \\
Cu4-N401 & 2.024 & W2-C21-N21 & 179.6 \\
Cu4-N402 & 2.016 & W2-C23-N23 & 176.5 \\
\hline
\end{tabular}

Projection along the $a$ and $b$ crystallographic directions (Figure 4) shows that the symmetrically independent molecules (marked red and blue) are arranged in independent layers in the (10-1) and (20-2) planes. They are bound into a 3D supramolecular network by the net of hydrogen bonds between cyanide ligands, NH groups of cyclam, aqua ligands, and crystallization water (Figure S5). The molecules of the same symmetry are bound within the layers by H-bonds formed by coordinated water, which donates two protons to two $\mathrm{CN}$ ligands of two neighboring molecules. The layers are linked by direct bonds between $\mathrm{CN}$ ligands and $\mathrm{NH}$ groups, as well as by $\mathrm{H}$-bonds between $\mathrm{CN}$-ligands mediated by crystallization water. 
$a$

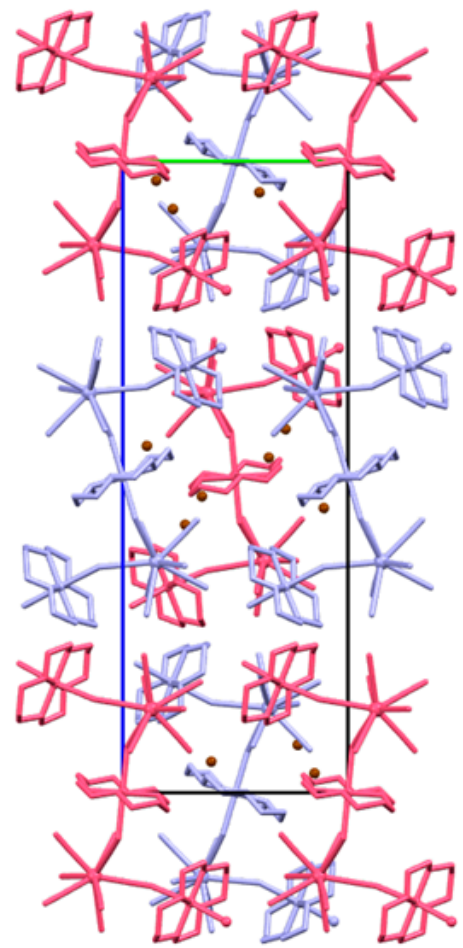

$b$

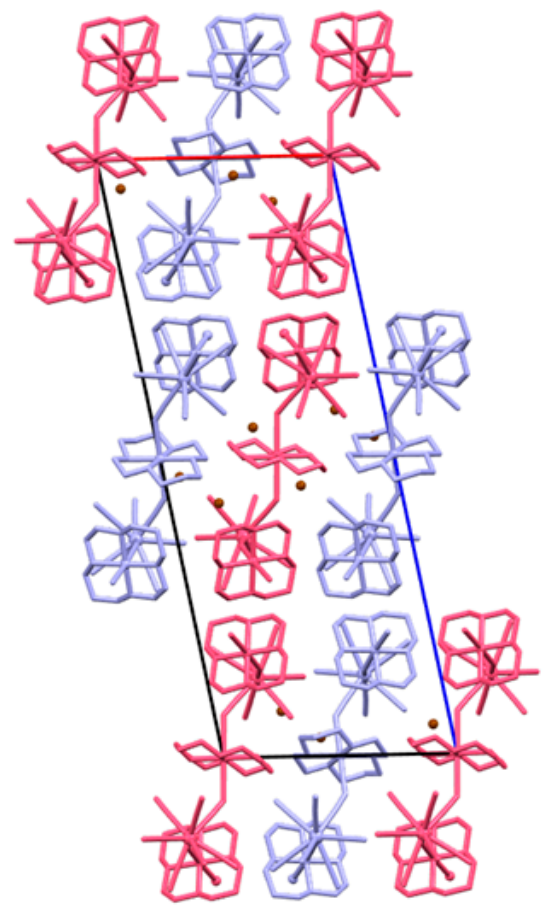

Figure 4. Projection of the structure of $2 \cdot 3 \mathbf{H}_{2} \mathrm{O}$ along $(\mathbf{a}, \mathbf{b})$ crystallographic directions; symmetrically independent molecules marked pink and violet.

\subsection{Magnetic Properties}

All compounds were characterized by DC susceptibility measurements at the applied field of 1000 Oe in the temperature range $1.8-300 \mathrm{~K}$ (Figure 5) and magnetization at $1.8 \mathrm{~K}$ in the field up to $70 \mathrm{kOe}$ (Figure 6). At the high temperature limit, the value of $\chi T$ for all compounds is close to the Curie constant of $1.88 \mathrm{~cm}^{3} \mathrm{~K} / \mathrm{mol}$, expected for three $\mathrm{Cu}^{\mathrm{II}}$ and two $\mathrm{W}^{\mathrm{V}}$ ions with $\mathrm{s}=1 / 2$ and $\mathrm{g}=2$, and it remains constant down to about $60 \mathrm{~K}$. Below that temperature, differences in magnetic behavior between the compounds become apparent. For $\mathbf{1} \cdot \mathbf{5} \mathrm{H}_{\mathbf{2}} \mathrm{O}$, where intra-chain interactions are predominantly ferromagnetic [22], the $\chi T$ curve rises slightly to reach the maximum of $2.03 \mathrm{~cm}^{3} \mathrm{~K} / \mathrm{mol}$ at $7.5 \mathrm{~K}$. For the dehydrated sample 1 , the $\chi T$ value decreases below $60 \mathrm{~K}$ down to $0.87 \mathrm{~cm}^{3} \mathrm{~K} / \mathrm{mol}$ at $1.8 \mathrm{~K}$, indicating predominantly antiferromagnetic interaction within the chains. This change in magnetic behavior can be attributed to the bending of the $\mathrm{CN}$-bridges. As was shown before [30-32] for $\mathrm{d}^{9}$ configuration, the bridge geometry strongly affects the character and strength of magnetic superexchange through the $\pi^{*}$ orbitals of $\mathrm{CN}^{-}$ions, which changes from ferromagnetic for a linear bridge to antiferromagnetic for strongly bent bridges. The antiferromagnetic character of intra-chain interactions in $\mathbf{1}$ is also visible in the magnetization at $1.8 \mathrm{~K}$. The increase of the magnetic moment in an increasing field is much slower for the dehydrated sample $\mathbf{1}$ than for $\mathbf{1} \cdot 5 \mathrm{H}_{2} \mathrm{O}$ and it reaches only $2.98 \mathrm{~N} \beta$ at $70 \mathrm{kOe}$, which is far from the expected saturation value of $5 \mathrm{~N} \beta$. The magnetic characteristic that we obtained for $\mathbf{1} \cdot \mathbf{5} \mathrm{H}_{\mathbf{2}} \mathrm{O}$ is very similar, but not identical with the published data [22]. Slightly lower values of magnetization and high-temperature susceptibility are most probably caused by the relatively low accuracy of small sample weight assessment. The difference in the $\chi T$ course in the low temperature range, where we observed a lower maximum at a slightly higher temperature, may be due to partial loss of water and onset of the structural transformation in one of the samples. 


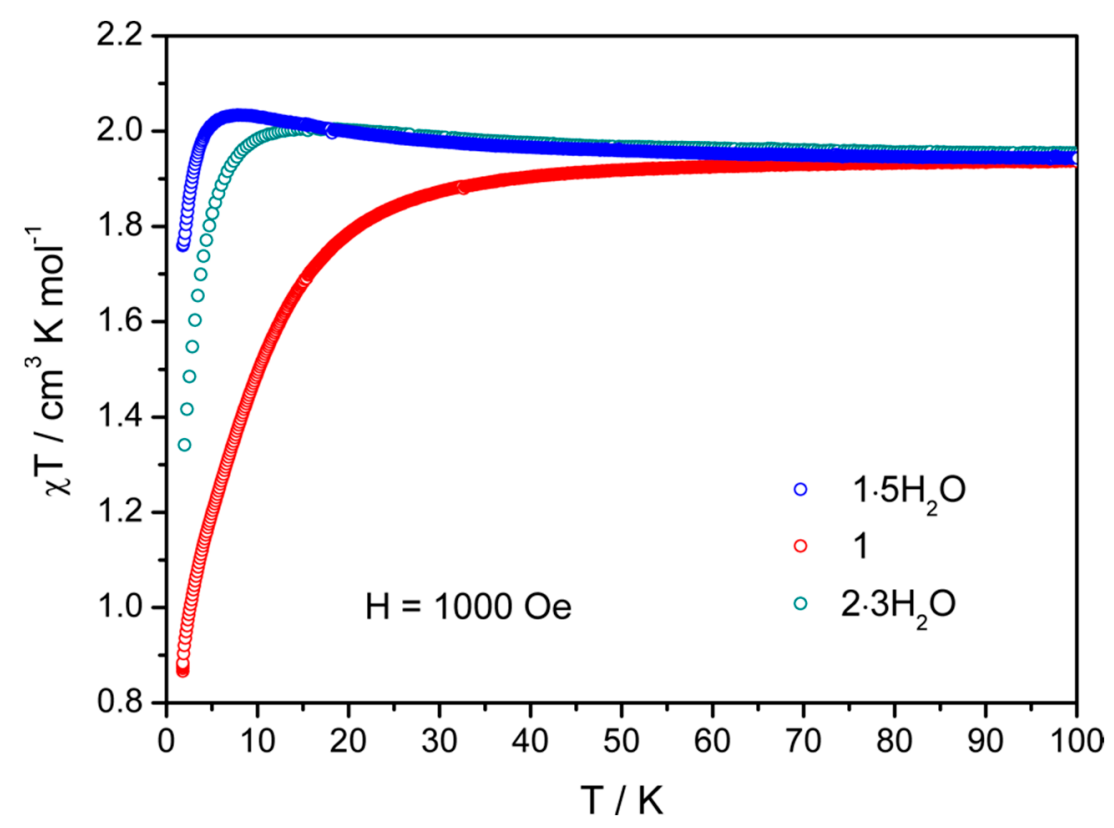

Figure 5. Temperature dependence of the DC magnetic susceptibility at 1000 Oe for $\mathbf{1} \cdot \mathbf{5} \mathbf{H}_{\mathbf{2}} \mathbf{O}, \mathbf{1}$ and $2 \cdot 3 \mathrm{H}_{2} \mathrm{O}$.

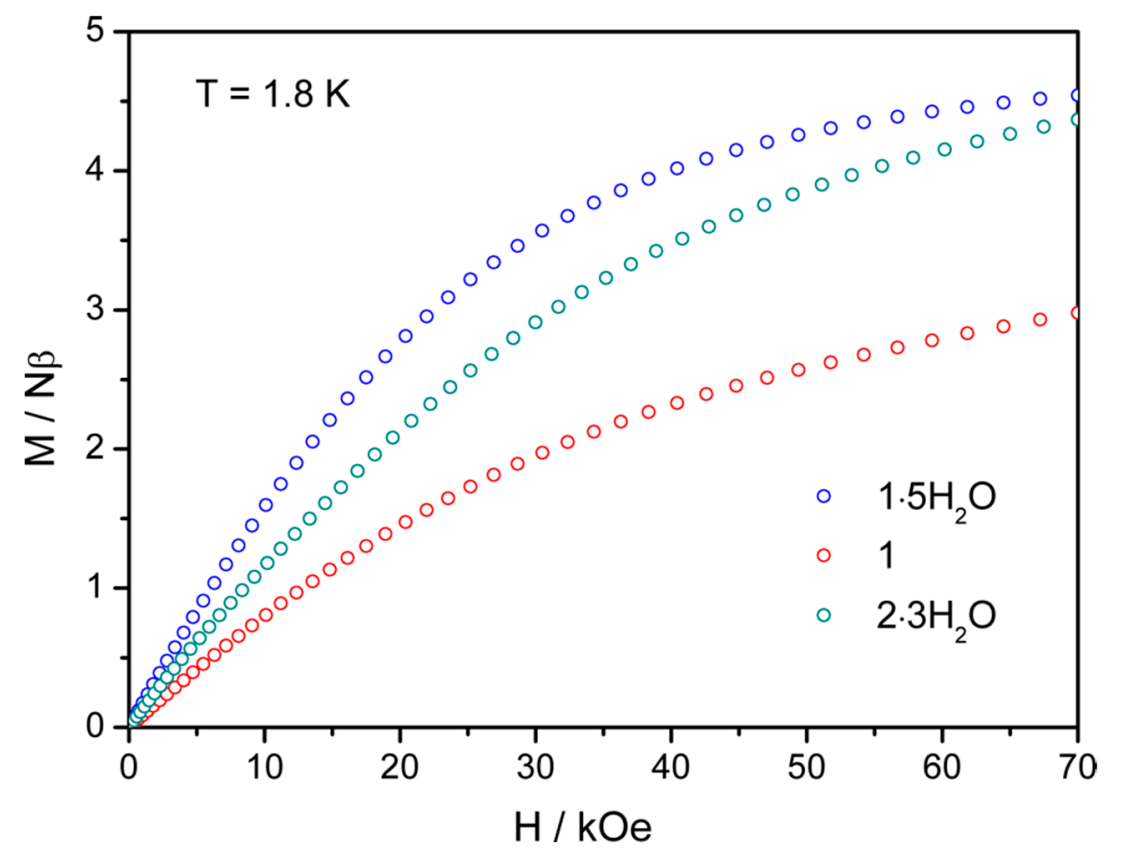

Figure 6. Field dependence of magnetization at $1.8 \mathrm{~K}$ for $\mathbf{1} \cdot 5 \mathrm{H}_{2} \mathrm{O}, \mathbf{1}$ and $\mathbf{2} \cdot \mathbf{3} \mathrm{H}_{\mathbf{2}} \mathrm{O}$.

The magnetic behavior of $\mathbf{2} \cdot \mathbf{3} \mathbf{H}_{\mathbf{2}} \mathrm{O}$ is similar to that of $\mathbf{1} \cdot \mathbf{5} \mathbf{H}_{\mathbf{2}} \mathrm{O}$. In the $\chi T$ dependence on $T$ (Figure 5), a slight increase below $60 \mathrm{~K}$ is observed with a broad maximum of $2.01 \mathrm{~cm}^{3} \mathrm{~K} / \mathrm{mol}$ at about $14 \mathrm{~K}$ and an abrupt drop below $7 \mathrm{~K}$. The magnetization curve lies slightly below the one of $\mathbf{1} \cdot \mathbf{5 H}_{\mathbf{2}} \mathbf{O}$ and at $70 \mathrm{kOe}$ reaches $4.37 \mathrm{~N} \beta$ (Figure 6). These results suggest the presence of weak intramolecular ferromagnetic interactions. This is consistent with the observed geometry of $\mathrm{CN}$-bridges, which in $\mathbf{2} \cdot \mathbf{3} \mathrm{H}_{2} \mathrm{O}$ is similar to that in $\mathbf{1} \cdot \mathbf{5} \mathrm{H}_{2} \mathrm{O}$.

\section{Conclusions}

We have shown that similarly to $[\mathrm{Ni}(\mathrm{cyclam})]^{2+/ 3+}$ complexes, the $[\mathrm{Cu}(\mathrm{cyclam})]^{2+}$ ion can be used as a cationic building block in combination with polycyanometallates to construct 


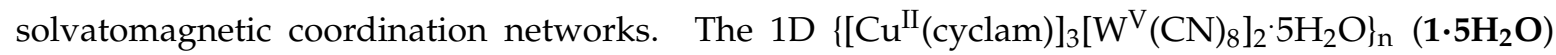
polymer exhibits a rare single-crystal-to-single-crystal structural transformation to the anhydrous $\left\{\left[\mathrm{Cu}^{\mathrm{II}}(\mathrm{cyclam})\right]_{3}\left[\mathrm{~W}^{\mathrm{V}}(\mathrm{CN})_{8}\right]_{2}\right\}_{n}$ (1) form. Although the topology of the compound is retained, the modification of bonds geometry and intermolecular interactions results in a noticeable change of magnetic properties, switching the predominant intra-chain interactions from ferromagnetic in $\mathbf{1} \cdot 5 \mathrm{H}_{\mathbf{2}} \mathrm{O}$ to antiferromagnetic in $\mathbf{1}$. The dehydration process is not fully reversible, probably due to the formation of intra-chain H-bonds, which stabilize strong bending of the CN-bridges. The rehydration causes collapse of the crystals and partial degradation of the sample. Apart from the post-synthetic modification of $\mathbf{1} \cdot 5 \mathrm{H}_{\mathbf{2}} \mathrm{O}$, we have also shown that the same building block can be arranged in a different structure by slight modification of synthetic conditions. The $\left\{\left[\mathrm{Cu}^{\mathrm{II}}(\mathrm{cyclam})\left(\mathrm{H}_{2} \mathrm{O}\right)\right]_{2}\left[\mathrm{Cu}^{\mathrm{II}}(\right.\right.$ cyclam $\left.\left.)\right]\left[\mathrm{W}^{\mathrm{V}}(\mathrm{CN})_{8}\right]_{2}\right\} \cdot 3 \mathrm{H}_{2} \mathrm{O}$ pentanuclear Z-shaped molecule $\left(\mathbf{2} \cdot \mathbf{3} \mathbf{H}_{2} \mathbf{O}\right)$, obtained from water under slow diffusion conditions, exhibits weak ferromagnetic interactions through CN-bridges.

Supplementary Materials: The following are available online at http:/ / www.mdpi.com/2073-4352/9/1/45/s1, Figure S1: PXRD pattern for the rehydrated sample of 1 in comparison to $1 \cdot 5 \mathrm{H}_{2} \mathrm{O}$ and 1; Figure S2: Mass loss upon dehydration of $1.5 \mathrm{H}_{2} \mathrm{O}$ monitored by dynamic vapor sorption method; Figure S3: PXRD pattern for sample obtained from $[\mathrm{Cu}($ cyclam $)]\left(\mathrm{NO}_{3}\right)_{2}$ and $\mathrm{Na}_{3}\left[\mathrm{~W}(\mathrm{CN})_{8}\right]$ by quick precipitation from water solution in comparison to $1 \cdot 5 \mathrm{H}_{2} \mathrm{O}$ and $2 \cdot 3 \mathrm{H}_{2} \mathrm{O}$; Table $\mathrm{S} 1$ : Continuous shape measure parameters for octa-coordinated $\mathrm{W}$ centers in the structures of $1 \cdot 5 \mathrm{H}_{2} \mathrm{O}, 1$ and $2 \cdot 3 \mathrm{H}_{2} \mathrm{O}$; Table S2: Continuous shape measure parameters for hexa-coordinated $\mathrm{Cu}$ centers of $1 \cdot 5 \mathrm{H}_{2} \mathrm{O}, 1$ and $2 \cdot 3 \mathrm{H}_{2} \mathrm{O}$; Figure S4: Inter- and intra-chain H-bonds in 1; Figure S5: Inter- and intra-molecular $\mathrm{H}$-bonds in $2 \cdot 3 \mathrm{H}_{2} \mathrm{O}$.

Author Contributions: Syntheses, original draft preparation: A.P.; crystal structures: A.P. and B.N.; magnetic characterization: M.R.; conceptualization, supervision, funding acquisition and project administration, manuscript review and editing: B.N.

Funding: This research was funded by Polish National Science Centre, grant number 2015/19/B/ST5/00922.

Conflicts of Interest: The authors declare no conflict of interest.

\section{References}

1. Kahn, O.; Larionova, J.; Yakhmi, J.V. Molecular Magnetic Sponges. Chem. Eur. J. 1999, 5, 3443-3449. [CrossRef]

2. Maspoch, D.; Ruiz-Molina, D.; Wurst, K.; Domingo, N.; Cavallini, M.; Biscarini, F.; Tejada, J.; Rovira, C.; Veciana, J. A nanoporous molecular magnet with reversible solvent-induced mechanical and magnetic properties. Nat. Mater. 2003, 2, 190-195. [CrossRef]

3. Pinkowicz, D.; Podgajny, R.; Gawel, B.; Nitek, W.; Lasocha, W.; Oszajca, M.; Czapla, M.; Makarewicz, M.; Balanda, M.; Sieklucka, B. Double Switching of a Magnetic Coordination Framework through Intraskeletal Molecular Rearrangement. Angew. Chem. Int. Edit. 2011, 50, 3973-3977. [CrossRef]

4. Nowicka, B.; Balanda, M.; Gawel, B.; Cwiak, G.; Budziak, A.; Lasocha, W.; Sieklucka, B. Microporous $\left\{[\mathrm{Ni}(\mathrm{cyclam})]_{3}\left[\mathrm{~W}(\mathrm{CN})_{8}\right]_{2}\right\}_{n}$ affording reversible structural and magnetic conversions. Dalton Trans. 2011, 40, 3067-3073. [CrossRef]

5. Nowicka, B.; Rams, M.; Stadnicka, K.; Sieklucka, B. Reversible Guest-Induced Magnetic and Structural Single-Crystal-to-Single-Crystal Transformation in Microporous Coordination Network $\left\{[\mathrm{Ni}(\mathrm{cyclam})]_{3}\left[\mathrm{~W}(\mathrm{CN})_{8}\right]_{2}\right\}_{n}$. Inorg. Chem. 2007, 46, 8123-8125. [CrossRef]

6. Nowicka, B.; Reczyński, M.; Bałanda, M.; Fitta, M.; Gawel, B.; Sieklucka, B. The Rule Rather than the Exception: Structural Flexibility of $[\mathrm{Ni}(\mathrm{cyclam})]^{2+}$-Based Cyano-Bridged Magnetic Networks. Cryst. Growth Des. 2016, 16, 4736-4743. [CrossRef]

7. Nowicka, B.; Reczyński, M.; Rams, M.; Nitek, W.; Kozieł, M.; Sieklucka, B. Larger pores and higher $T_{c}$ : $\left\{[\mathrm{Ni}(\mathrm{cyclam})]_{3}\left[\mathrm{~W}(\mathrm{CN})_{8}\right]_{2} \cdot \operatorname{solv}\right\}_{n}-\mathrm{A}$ new member of the largest family of pseudo-polymorphic isomers among octacyanometallate-based assemblies. CrystEngComm 2015, 17, 3526-3532. [CrossRef]

8. Nowicka, B.; Heczko, M.; Reczyński, M.; Rams, M.; Gawel, B.; Nitek, W.; Sieklucka, B. Exploration of a new building block for the construction of cyano-bridged solvatomagnetic assemblies: $[\mathrm{Ni}(\mathrm{cyclam})]^{3+}$. CrystEngComm 2016, 18, 7011-7020. [CrossRef] 
9. Nowicka, B.; Reczyński, M.; Rams, M.; Nitek, W.; Zukrowski, J.; Kapusta, C.; Sieklucka, B. Hydration-switchable charge transfer in the first bimetallic assembly based on the $[\mathrm{Ni}(\mathrm{cyclam})]^{3+}$-Magnetic $\mathrm{CN}$-bridged chain $\left\{\left(\mathrm{H}_{3} \mathrm{O}\right)\left[\mathrm{Ni}^{\mathrm{III}}(\text { cyclam })\right]\left[\mathrm{Fe}^{\mathrm{II}}(\mathrm{CN})_{6}\right] \cdot 5 \mathrm{H}_{2} \mathrm{O}\right\}_{n}$. Chem. Commun. 2015, 51, 11485-11488. [CrossRef]

10. Reczyński, M.; Nowicka, B.; Näther, C.; Kozieł, M.; Nakabayashi, K.; Ohkoshi, S.-I.; Sieklucka, B. Dehydration-Triggered Charge Transfer and High Proton Conductivity in $\left(\mathrm{H}_{3} \mathrm{O}\right)\left[\mathrm{Ni}^{\mathrm{III}}(\right.$ cyclam $\left.)\right]\left[\mathrm{M}^{\mathrm{II}}(\mathrm{CN})_{6}\right]$ ( $\mathrm{M}=\mathrm{Ru}, \mathrm{Os}$ ) Cyanide-Bridged Chains. Inorg. Chem. 2018, 57, 13415-13422. [CrossRef]

11. Colacio, E.; Dominguez-Vera, J.M.; Ghazi, M.; Moreno, J.M.; Kivekas, R.; Lloret, F.; Stoeckli-Evans, H. A novel two-dimensional honeycomb-like bimetallic iron(III)-nickel(II) cyanide-bridged magnetic material $[\mathrm{Ni}(\text { cyclam })]_{3}\left[\mathrm{Fe}(\mathrm{CN})_{6}\right]_{2} \cdot n \mathrm{H}_{2} \mathrm{O}$ (cyclam $=1,4,8,11$-tetraazacyclodecane). Chem. Commun. 1999, 987-988. [CrossRef]

12. Ferlay, S.; Mallah, T.; Vaissermann, J.; Bartolome, F.; Veillet, P.; Verdaguer, M. A chromium(III) nickel(II) cyanide-bridged ferromagnetic layered structure with corrugated sheets. Chem. Commun. 1996, 21, 2481-2482. [CrossRef]

13. Hiroko, T.; Kosuke, N.; Koji, N.; Toshinori, K.; Kazuhito, H.; Shin-ichi, O. Photoreversible Switching of Magnetic Coupling in a Two-dimensional Copper Octacyanomolybdate. Chem. Lett. 2009, 38, 338-339. [CrossRef]

14. Larionova, J.; Clérac, R.; Donnadieu, B.; Willemin, S.; Guérin, C. Synthesis and Structure of a Two-Dimensional Cyano-Bridged Coordination Polymer $[\mathrm{Cu}(\text { cyclam })]_{2}\left[\mathrm{Mo}(\mathrm{CN})_{8}\right] \cdot 10.5 \mathrm{H}_{2} \mathrm{O}(\mathrm{Cyclam}=$ 1,4,8,11-Tetraazacyclodecane). Cryst. Growth Des. 2003, 3, 267-272. [CrossRef]

15. Long, J.; Chamoreau, L.-M.; Marvaud, V. Supramolecular Heterotrimetallic Assembly Based on Octacyanomolybdate, Manganese, and Copper. Eur. J. Inorg. Chem. 2011, 2011, 4545-4549. [CrossRef]

16. Colacio, E.; Domínguez-Vera, J.M.; Ghazi, M.; Kivekäs, R.; MaríaMoreno, J.; Pajunen, A. Structure and magnetic properties of two cyanide-bridged one-dimensional M-CuII ( $\mathrm{M}=$ FeIII or FeII) bimetallic assemblies from ferricyanide and $\mathrm{CuN}^{2+}(\mathrm{N} 4=1,4,8,11$-tetraazacyclotetradecane and N,N'-bis(2-pyridylmethylene)-1,3-propanediamine) building blocks. J. Chem. Soc. Dalton Trans. 2000, 4, 505-509. [CrossRef]

17. Salah El Fallah, M.; Ribas, J.; Solans, X.; Font-Bardia, M. A new one-dimensional ferromagnet based on copper(II) and hexacyanochromate(III), with a rope-ladder chain structure. New J. Chem. 2003, 27, 895-898. [CrossRef]

18. Sen, R.; Bhattacharya, A.; Mal, D.; Bhattacharjee, A.; Gütlich, P.; Mukherjee, A.K.; Solzi, M.; Pernechele, C.; Koner, S. A cyano-bridged bimetallic ferrimagnet: Synthesis, X-ray structure and magnetic study. Polyhedron 2010, 29, 2762-2768. [CrossRef]

19. Iijima, S.; Honda, Z.; Koner, S.; Mizutani, F. Magnetic and Mössbauer studies of cyanide-bridged bimetallic assembly [Mn(cyclam)][Fe(CN) 6 ] $3 \mathrm{H}_{2}$ O. J. Magn. Magn. Mater. 2001, 223, 16-20. [CrossRef]

20. Bhattacharjee, A.; Miyazaki, Y.; Nakazawa, Y.; Koner, S.; Iijima, S.; Sorai, M. Study of the magnetic phase transition in a cyanide-bridged molecule-based material: $[\mathrm{Mn}($ cyclam $)]\left[\mathrm{Fe}(\mathrm{CN})_{6}\right] \cdot 3 \mathrm{H}_{2} \mathrm{O}$ (cyclam=1,4,8,11-tetraazacyclotetradecane). Phys. B Condens. Matter 2001, 305, 56-64. [CrossRef]

21. Nowicka, B.; Heczko, M.; Rams, M.; Reczyński, M.; Gaweł, B.; Nitek, W.; Sieklucka, B. Solvatomagnetic Studies on Cyano-Bridged Bimetallic Chains Based on [Mn(cyclam) $]^{3+}$ and Hexacyanometallates. Eur. J. Inorg. Chem. 2017, 1, 99-106. [CrossRef]

22. Lim, J.H.; You, Y.S.; Yoo, H.S.; Yoon, J.H.; Kim, J.I.; Koh, E.K.; Hong, C.S. Bimetallic $\mathrm{M}^{\mathrm{V}}{ }_{2} \mathrm{Cu}^{\mathrm{II}}{ }_{3}(\mathrm{M}=\mathrm{Mo}$, W) Coordination Complexes Based on Octacyanometalates: Structures and Magnetic Variations Tuned by Chelated Tetradentate Macrocyclic Ligands. Inorg. Chem. 2007, 46, 10578-10586. [CrossRef]

23. Samotus, A. Photochemical Properties of Octacyanotnagstic Acids. 2. Photolisys of Octacyanotungstic(V) Acid. Pol. J. Chem. 1973, 47, 265-278.

24. Berry, D.E.; Girard, S.; McAuley, A. The Synthesis and Reactions of Nickel(III) Stabilized by a Nitrogen-Donor Macrocycle. J. Chem. Educ. 1996, 73, 551. [CrossRef]

25. Sheldrick, G. A short history of SHELX. Acta Crystallogr. A 2008, 64, 112-122. [CrossRef]

26. Llunell, M.; Casanova, D.; Cirera, J.; Alemany, P.; Alvarez, S. SHAPE v. 2.1; University of Barcelona: Barcelona, Spain, 2013. 
27. Korzeniak, T.; Jankowski, R.; Kozieł, M.; Pinkowicz, D.; Sieklucka, B. Reversible Single-Crystal-to-SingleCrystal Transformation in Photomagnetic Cyanido-Bridged $\mathrm{Cd}_{4} \mathrm{M}_{2}$ Octahedral Molecules. Inorg. Chem. 2017, 56, 12914-12919. [CrossRef]

28. Reczyński, M.; Chorazy, S.; Nowicka, B.; Sieklucka, B.; Ohkoshi, S.-I. Dehydration of Octacyanido-Bridged $\mathrm{Ni}^{\mathrm{II}}-\mathrm{W}^{\mathrm{IV}}$ Framework toward Negative Thermal Expansion and Magneto-Colorimetric Switching. Inorg. Chem. 2017, 56, 179-185. [CrossRef]

29. Nowicka, B.; Balanda, M.; Reczyński, M.; Majcher, A.M.; Koziel, M.; Nitek, W.; Lasocha, W.; Sieklucka, B. A water sensitive ferromagnetic [ $\mathrm{Ni}($ cyclam $)]_{2}\left[\mathrm{Nb}(\mathrm{CN})_{8}\right]$ network. Dalton Trans. 2013, 42, 2616-2621. [CrossRef]

30. Lim, J.H.; Yoon, J.H.; Choi, S.Y.; Ryu, D.W.; Koh, E.K.; Hong, C.S. Cyano-Bridged Pentanuclear and Honeycomblike $\mathrm{M}^{\mathrm{III}} \mathrm{Cu}^{\mathrm{II}}(\mathrm{M}=\mathrm{Fe}, \mathrm{Cr})$ Bimetallic Assemblies: Structural Variations Modulated by Side Groups of Macrocyclic Ligands and Magnetic Properties. Inorg. Chem. 2011, 50, 1749-1757. [CrossRef]

31. Marvaud, V.; Decroix, C.; Scuiller, A.; Tuyèras, F.; Guyard-Duhayon, C.; Vaissermann, J.; Marrot, J.; Gonnet, F.; Verdaguer, M. Hexacyanometalate Molecular Chemistry: Di-, Tri-, Tetra-, Hexa- and Heptanuclear Heterobimetallic Complexes; Control of Nuclearity and Structural Anisotropy. Chem. Eur. J. 2003, 9, 1692-1705. [CrossRef]

32. Tuyèras, F.; Scuiller, A.; Duhayon, C.; Hernandez-Molina, M.; de Biani, F.F.; Verdaguer, M.; Mallah, T.; Wernsdorfer, W.; Marvaud, V. Hexacyanidometalate molecular chemistry, part III: Di-, tri-, tetra-, hexa- and hepta-nuclear chromium-nickel complexes: Control of spin, structural anisotropy, intra- and inter-molecular exchange couplings. Inorg. Chim. Acta 2008, 361, 3505-3518. [CrossRef]

(C) 2019 by the authors. Licensee MDPI, Basel, Switzerland. This article is an open access article distributed under the terms and conditions of the Creative Commons Attribution (CC BY) license (http:/ / creativecommons.org/licenses/by/4.0/). 